\title{
Ecology and Epidemiology of Whitefly-Transmitted Closteroviruses
}

\author{
G. C. Wisler, J. E. Duffus, H.-Y. Liu, and R. H. Li \\ USDA-ARS, Salinas, CA
}

\section{Closterovirus Taxonomy}

Our concept of the closterovirus group has changed significantly in the past several years and continues to change as more members are discovered. The earliest recognized and most notable viruses in what is now considered to be the family Closteroviridae (63) included beet yellows virus (BYV), beet yellow stunt virus (BYSV), carnation necrotic fleck virus (CNFV), and citrus tristeza virus (CTV) (3). Membership in the closterovirus group required two basic characteristics: highly flexuous, extremely long particles $(1,200$ to $2,000 \mathrm{~nm}$ ) (Fig. 1) with distinct crossbanding, and transmission by aphids in a semipersistent manner (37). An additional characteristic that has been well documented is their phloem-limited nature and the formation of membranous vesicles in the cytoplasm of phloem cells $(34,35,39)$. Later, classification of closteroviruses divided members into two subgroups based on particle lengths: long types with particles ranging from 1,200 to $2,000 \mathrm{~nm}$, and short types with particles ranging from 700 to $800 \mathrm{~nm}(18,51)$. Long particle closteroviruses were typically transmitted by aphids in a semipersistent manner. The short particle closteroviruses, some of which we know to be bipartite, are transmitted by whiteflies.

As closterovirus taxonomy has evolved, some important new properties have been added, so that two genera have been proposed for the family Closteroviridae. The genus Closterovirus was proposed to in-

Dr. Wisler's address is: USDA-ARS Crop Improvement and Protection Unit, Salinas, CA;

E-mail: gwisler@asrr.arsusda.gov

Publication no. D-1997-1223-01F

(C) 1998 The American Phytopathological Society clude the monopartite members that are aphid-transmitted, and the genus Crinivirus was proposed to include members that are bipartite and whitefly-transmitted (G. P. Martelli, personal communication). As we learn more about their molecular properties, additional characteristics have been added to the description of the Closteroviridae (57). A characteristic ubiquitous to all closteroviruses described to date is the presence of a virus-encoded heat shock protein (HSP70) homolog as a unique gene product $(1,18,45,46,58)$. A second gene product that is characteristic of the Closteroviridae is a diverged duplicate of the coat protein (7). The unique genome organization and gene expression strategies are shared among members of the Closteroviridae whether they are monopartite or bipartite (for reviews see Agranovsky et al. [1], Karasev et al. [44], and Klaassen et al. $[45,46])$.

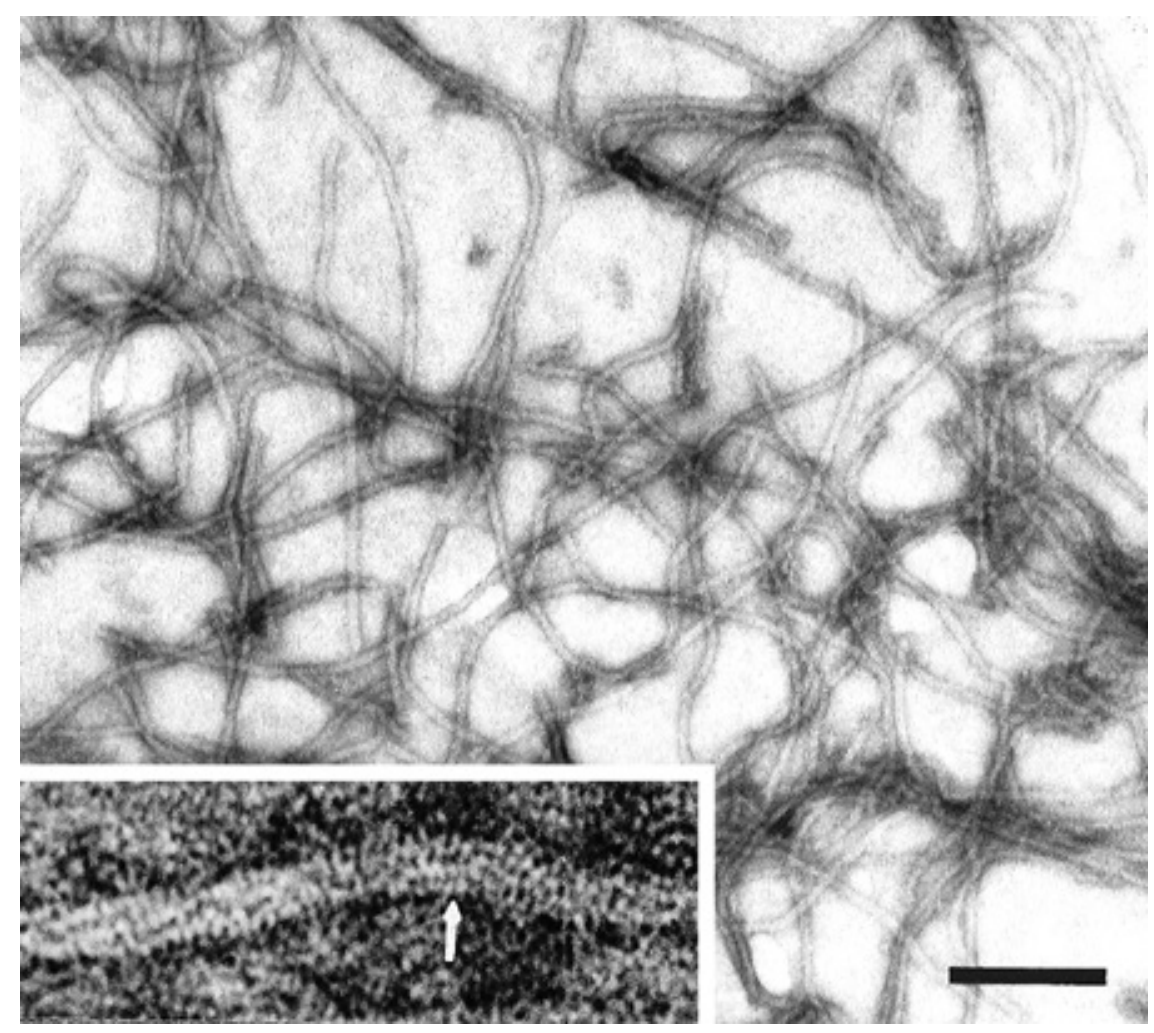

Fig. 1. Flexuous particles from a purified preparation of lettuce infectious yellows virus. Arrow in inset shows helical arrangement of protein subunits. Bar $=200 \mathbf{n m}$. 


\section{Whitefly-Transmitted Closteroviruses}

The rapidly growing group of whiteflytransmitted closteroviruses includes beet pseudo-yellows virus (BPYV) (20), cucurbit yellow stunting disorder virus (CYSDV) (11), lettuce infectious yellows virus (LIYV) $(30,45,46)$, lettuce chlorosis virus (LCV) (33), tomato infectious chlorosis virus (TICV) $(32,81)$, tomato chlorosis virus (ToCV) $(78,79)$, and a group of related closterovirus isolates infecting sweet potato termed sweet potato chlorotic stunt virus (SPCSV) (40,41,66,74-76). In addition, LIYV, CYSDV, TICV, ToCV, and SPCSV have bipartite genomes $(11,40,41,45,46,79,81)$ with particle lengths approximately onehalf that of aphid-transmitted closteroviruses. The first report of the length of LIYV particles was based on the longest particles measured (30). Reevaluation of the particle length of LIYV based on more than 250 particles measured shows the modal length to be within the range of the short particle bicomponent closteroviruses (H.-Y. Liu, unpublished data). One example in the literature of a whitefly-transmitted clostero-like virus, cucumber chlorotic spot virus (CCSV), is different from the Crinivirus genus proposed above by having a monopartite genome of $15.5 \mathrm{~kb}$ and is whitefly-transmitted, but sequence information has not been published (82).

\section{Changes in Whitefly Populations}

Whitefly populations have drastically increased throughout the world since the 1970s, particularly in tropical and subtropical areas $(8,14)$ (Fig. 2). For example, populations of Bemisia tabaci (Gennadius) collected in Imperial Valley of California increased 300-fold from the mid-1970s to the mid-1980s, and 1,600-fold from the mid-1970s to the mid-1990s (J. E. Duffus, unpublished) (Fig. 2C). The cause of this increase is unknown, but it may be due to the combined effects of increased use of synthetic organic insecticides and subsequent increased resistance to pesticides $(23,24,61,62)$, changing climatic conditions (global warming), intensified agricultural practices, and international movement of plant materials in the nursery and horticultural trade $(14,16)$.

Several biotypes of $B$. tabaci have been described; two in particular, biotypes A and $\mathrm{B}$, transmit agriculturally important viruses. Biotype A was the predominant biotype in the southern United States until the late 1980s. Biotype B had displaced biotype A throughout the Sunbelt states by $1991(9,14,52)$ and was responsible for the dramatic population increases being reported. This B biotype of B. tabaci caused silvering on squash and thus was given the vernacular name, silverleaf whitefly. Others have proposed that the B biotype is a separate species, Bemisia argentifolii $(5,59)$, but the B biotype is regarded as the more accepted designation worldwide $(8,52,56)$.

Concurrent with the increase of whiteflies worldwide has been the increase in
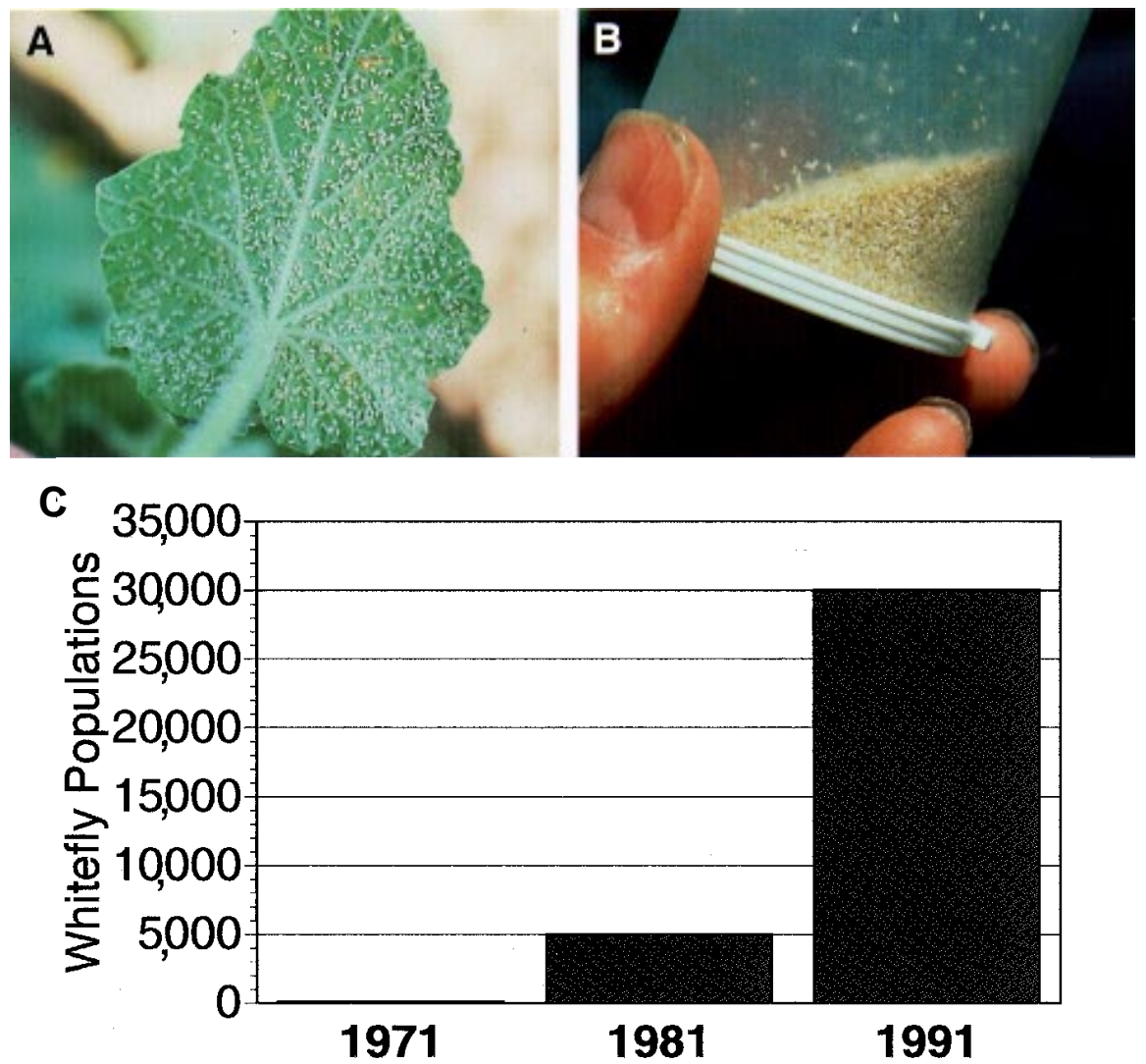

Fig. 2. (A) Masses of whiteflies on the underside of a melon leaf in the Imperial Valley of California. (B) Whiteflies collected in 2 min from a cucurbit planting using a handheld vacuum collection device (15). (C) Relative numbers of whiteflies periodically collected from melon and cotton plantings in 2-min intervals using a hand-held vacuum collection device, 1971 to 1991.
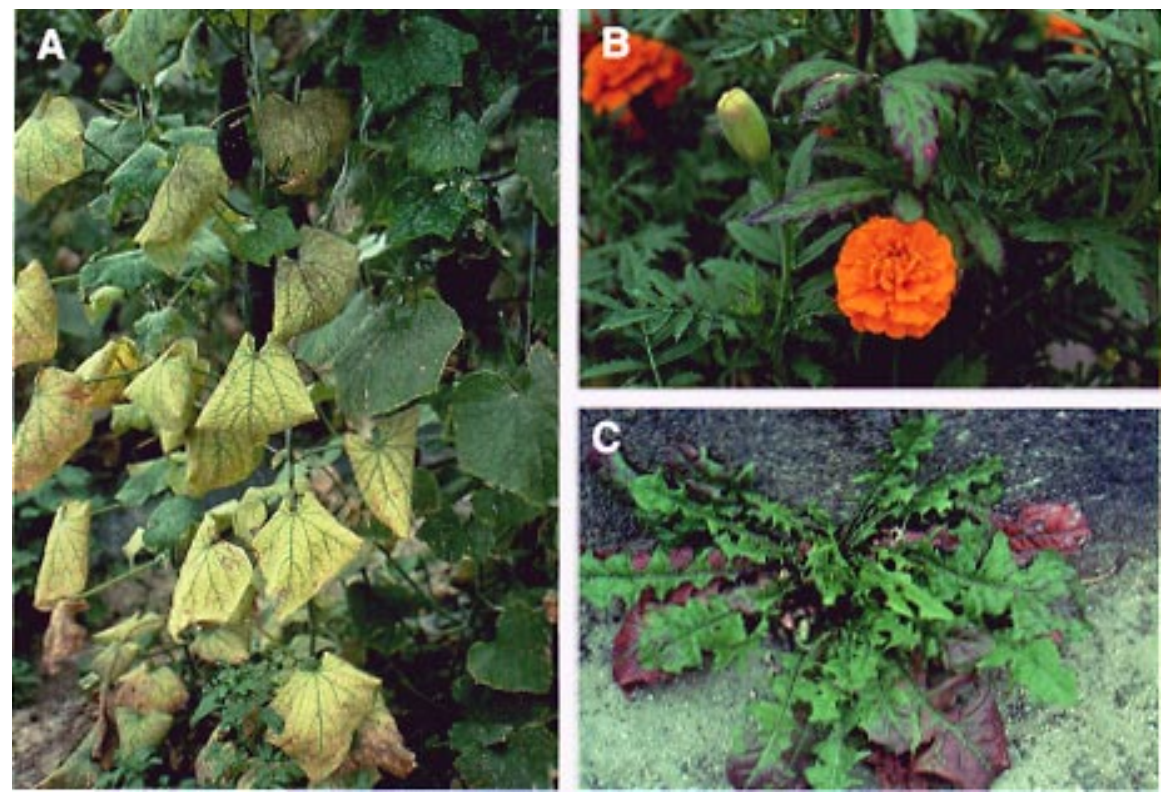

Fig. 3. Beet pseudo-yellows virus infecting (A) cucumber, (B) Tagetes sp. (marigold), and $(C)$ dandelion showing characteristic symptoms of interveinal yellowing and flecking on the cucurbits and interveinal reddening on marigold and dandelion. 
yield-limiting diseases and distinctive symptoms in infected plants, reflecting the names assigned to them, including tomato yellow leaf curl virus (TYLCV) and bean golden mosaic virus (BGMV). TYLCV has been cited as the most destructive and perhaps the most widespread tomato virus world wide. Losses in many important crops have been reported to be 30 to $100 \%$ worldwide due to whitefly-transmitted geminiviruses in the past decade (for a review see Brown [8]). Between 1990 and 1992, \$12 million in losses were attributed to TYLCV in the Dominican Republic alone (70).

In contrast to the geminiviruses, which $S$ plants, whitefly-transmitted closteroviruses (WTCs) typically cause symptoms that are easily attributed to other causes, such as physiological or nutritional disorders, or even pesticide phytotoxicity. In spite of these atypical virus symptoms, diseases caused by LIYV, the type member of the newly proposed genus Crinivirus of the family Closteroviridae, caused losses due to infections of lettuce, sugar beets, and melons reaching $\$ 20$ million in a single growing season in 1981 (30). In addition to causing difficult-to-recognize virus symptoms, the WTCs usually exist in low titers in infected plants and are generally restricted to the phloem tissue, thus making diagnosis and isolation even more difficult. It also is likely that the WTCs exist as mixed infections (65) with the more conspicuous geminiviruses and thus have gone unnoticed.

The artificial group of viruses inducing stunting, interveinal yellowing, or reddening of affected plants, viruses with special affinities to the phloem, have been designated the most important plant viruses in relation to crop damage (21). Luteoviruses and closteroviruses inducing the so-called yellow plague have been overlooked for too long because of the similarity of the symptoms to what agriculturists expect from poor fertility, poor moisture conditions, insect feeding, and natural aging or ripening. This article is an attempt to draw attention to a newly emerging group of the ubiquitous yellowing viruses. We discuss herein the most studied members of the group of WTCs with respect to their major hosts, their whitefly vectors, and epidemiological and ecological implications of host range, vector relationships, vector movement, and virus diversity.

\section{BPYV}

The first WTC described was BPYV, which was isolated from California greenhouses in 1965 (20,53). The greenhouse whitefly (Trialeurodes vaporariorum Westwood), one of the most important pests of greenhouse crops throughout the world, is the only vector. BPYV has a broad host range of crops, weeds, and ornamentals. Some of these hosts include spinach, endive, lettuce, squash, cucumber, muskmelon, sugar beet, carrot, dandelion, Gomphrena, Callistephus, Aguilegia, Tagetes (marigold), zinnia, and Godetia sp. (Fig. 3) (29; G. C. Wisler and J. E. Duffus, unpublished data). BPYV was first described in the United States in the early $1960 \mathrm{~s}$ and was subsequently found throughout the world $(20,29,42,54,55,64$, $69,73,83)$. The diagnosis of BPYV was based on transmission by the greenhouse whitefly and host range tests. In two instances, T. vaporariorum-transmitted entities, cucumber yellows virus (CYV) (83) and muskmelon yellows virus (MYV) (54), appeared to have host ranges somewhat distinct from BPYV and were thus considered to be distinct entities. More recent evidence (86) indicated that the insect transmission and host range characteristics of CYV were identical to those of BPYV. CYV reported from Japan as distinct from BPYV based on host range should now probably be considered to be BPYV. MYV was reported to be restricted to the Cucurbitaceae, but the authors indicated that improvement of transmission techniques could modify the results (55). Thus, the causal agent of the melon yellowing disease in France appears similar or identical to BPYV. Cucumber chlorotic spot virus (CCSV), another probable synonym for BPYV, was selected from cucumber in France and partially characterized at the molecular level (82). Attempts were not made to distinguish this virus from BPYV. A melon yellowing disease in Spain (43) is very similar or identical to BPYV based on vector, insect relationships, and host reaction on cucurbits, lettuce, and weed hosts. Reported particle lengths differ, but modal lengths are difficult to measure accurately because of their flexibility, entanglements, breaking, and diverse staining techniques.

At the present time, it would appear that only one Trialeurodes-transmitted virus, BPYV, affects the Cucurbitaceae, and that synonyms of the virus are cucumber yellows virus (83), muskmelon yellows virus, (55) cucumber infectious chlorosis virus (42), cucumber chlorotic spot virus (82), and melon yellows virus (43). Coffin and Coutts (12) examined several Trialeurodestransmitted virus isolates infecting cucurbits from France, the Netherlands, Spain,

Table 1. Some distinguishing characteristics of whitefly-transmitted closteroviruses ${ }^{\mathrm{a}}$

\begin{tabular}{|c|c|c|c|c|c|c|c|c|}
\hline Characteristic & BPYV' & CYSDV & LIYV & LCV & TICV & ToCV & AYV & $\overline{\text { SPCSV }}$ \\
\hline Vector specificity ${ }^{c}$ & T.v. only & $B>A$ & $A \gg B$ & $A=B$ & T.v. only & T.v., T.a., A, B & T.a. & B only? \\
\hline Persistence (days) & 7 days & 9 days & 3 days & 4 days & 3 days & 1 day & 3 days & \\
\hline Half-life $(h)^{d}$ & $64.0 \mathrm{~h}$ & $72.2 \mathrm{~h}$ & $23.5 \mathrm{~h}$ & $46.4 \mathrm{~h}$ & $23.5 \mathrm{~h}$ & $12.6 \mathrm{~h}$ & $24.9 \mathrm{~h}$ & $?$ \\
\hline Distribution $^{\mathrm{e}}$ & World & Mideast & SW-USA & SW-USA & CA,NC,It & $\mathrm{FL}, \mathrm{LA}, \mathrm{CO}$ & IL & World \\
\hline Host range & Wide & Narrow & Wide & Wide & Wide & Wide & Medium & Narrow \\
\hline Sugar beets & + & - & + & + & - & + & - & - \\
\hline Cucurbits & + & + & + & - & - & - & - & - \\
\hline Tomato & - & - & - & - & + & + & - & - \\
\hline Phloem-limited & + & + & + & + & + & + & + & + \\
\hline Vesicles & + & $?$ & + & + & + & + & + & + \\
\hline Coat protein (kDa) & $?$ & $?$ & 28 & 33 & 31 & $31 ?$ & $?$ & 29 \\
\hline RNA(s) & $1 ?$ & 2 & 2 & $?$ & 2 & 2 & 2 & 2 \\
\hline Size $(k b p)^{f}$ & & $8.0,9.0$ & $7.4,8.0$ & & $7.4,7.8$ & $7.8,8.2$ & $7.8,8.2$ & $7.5,8.5$ \\
\hline
\end{tabular}

a All particle lengths are within the range of short-particle closteroviruses, from 700 to $950 \mathrm{~nm}(11 ; \mathrm{H}$.-Y. Liu, unpublished).

b BPYV: beet pseudo-yellows virus; CYSDV: cucurbit yellow stunting disorder virus; LIYV: lettuce infectious yellows virus; LCV: lettuce chlorosis virus; TICV: tomato infectious chlorosis virus; ToCV: tomato chlorosis virus; AYV: abutilon yellows virus; SPCSV: sweet potato chlorotic stunt virus.

c $T . v .=$ greenhouse whitefly $($ Trialeurodes vaporariorum $) ; \mathrm{A}=$ sweet potato whitefly $($ Bemisia tabaci biotype A); $\mathrm{B}=$ silverleaf whitefly $($ B. argentifolii or B tabaci biotype B); T.a. = banded whitefly $($ T. abutilonea $)$; > indicates a greater transmission efficiency; = indicates relatively equivalent efficiency; ? indicates information has not been determined.

d Half-life as defined by Yarwood and Sylvester (83).

e Abbreviations are according to postal addresses for the United States; It = Italy; SW = southwest.

f See references $(11,40,45,46,79,80,81)$. 
and Turkey by reverse transcription-polymerase chain reaction (RT-PCR) of the HSP70 fragment, which was found to have a nearly identical sequence to BPYV, indicating a close relationship among diverse geographical locations.

BPYV has been responsible for significant economic losses in cucurbit crops in North America, Europe, and Asia. The increase in greenhouse production of melons and other vegetable crops $(11,68)$ has provided prime conditions for the greenhouse whitefly vector $T$. vaporariorum in areas where it would not normally survive, and for the spread of BPYV. Symptoms of BPYV in cucurbits appear first as chlorotic angular spots on lower leaves. The interveinal areas of leaves eventually become completely chlorotic except for the veins, which remain green. As infection progresses, the plants become more yellow, although young leaves appear normal. These symptoms, like those caused by all of the WTCs discussed in this article, are usually confused with physiological and/or nutritional disorders, soil $\mathrm{pH}$, micronutrient deficiencies, natural senescence, and even pesticide phytotoxicity. For this reason, these virus-induced diseases are difficult for growers, diagnosticians, and researchers alike to recognize. A characteristic feature that distinguishes infection by this group of viruses from the disorders listed above is the thickening and brittleness of symptomatic leaves. Leaves of infected plants snap when they are crushed in one's hand.

Because of its particle morphology and whitefly transmission, BPYV was presumed to be a closterovirus or clostero-like virus. The virus is retained in the vector for 6 days in daily serial transfers and has an estimated half-life (84) of $64.0 \mathrm{~h}$, suggest-
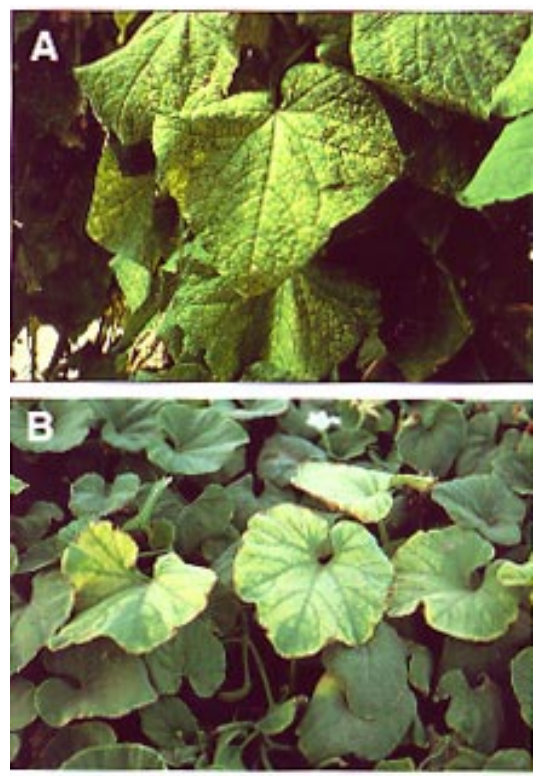

Fig. 4. Characteristic symptoms of cucurbit yellow stunting disorder virus on (A) cucumber and (B) melon. ing a semipersistent manner of transmission (Table 1). The rate at which inoculativity decreases is measurable in hours rather than minutes, as in the nonpersistent relationship, or many days, as in the case of the persistent type of transmission (22). The WTCs are retained for periods that range from 1 day (ToCV) to 9 days (CYSDV) (J. E. Duffus, unpublished results), which is an important diagnostic feature. Due to the difficulty in purifying BPYV, it has only been partially characterized. Recent evidence $(17,72)$ showed sequence data from a small portion of the C-terminal region of the BPYV HSP70 coding region aligned with those homologous sequences of BYV, CTV, and LIYV, thus confirming its relationship with members of the Closteroviridae. The international movement of hosts susceptible to BPYV and their resident vectors, particularly vegetatively propagated greenhouse ornamentals, and the wide host range of BPYV suggest that BPYV may be more widespread than has been recognized. Thus, the full impact and economic significance of this virus may have been underestimated.

\section{CYSDV}

A disease of cucurbit crops induced by CYSDV was first detected in the United Arab Emirates (UAE) in 1982 (38). It causes symptoms indistinguishable from those caused by BPYV (Fig. 4). This virus has been recently added to the growing list of whitefly-transmitted, bipartite closteroviruses with particle lengths reported to be similar to those of others ( 825 to 900 nm) (11). CYSDV also contains an HSP70 coding region $(11,72)$. Using a probe made to a portion of the CYSDV HSP70 gene (clone kindly provided by $\mathrm{T}$. Tian), we have identified CYSDV in cucurbits from Jordan, Saudi Arabia, Turkey, Egypt, Spain, and Israel. Although CYSDV causes symptoms similar to those of BPYV, it can be readily distinguished from BPYV by differences in vector specificity, retention in the whitefly vector, and host range restricted to the Cucurbitaceae (11) (Table 1). BPYV is only transmitted by the greenhouse whitefly, whereas CYSDV is transmitted efficiently by $B$. tabaci biotype $\mathrm{B}$ and relatively inefficiently by $B$. tabaci biotype $A$, but not by the greenhouse whitefly (J. E. Duffus and G. C. Wisler, unpublished results). The CYSDV persists in the vector for 9 days in serial, daily transfers and has a 72.2-h half-life in the vector, the longest retention time documented among the WTCs. The persistence and specificity of transmission of CYSDV and other viruses addressed in this article are unique biological characters for their differentiation (Fig. 5). The specificity of transmission of CYSDV, a virus that has only been found in the Old World, coincides with the occurrence of its whitefly

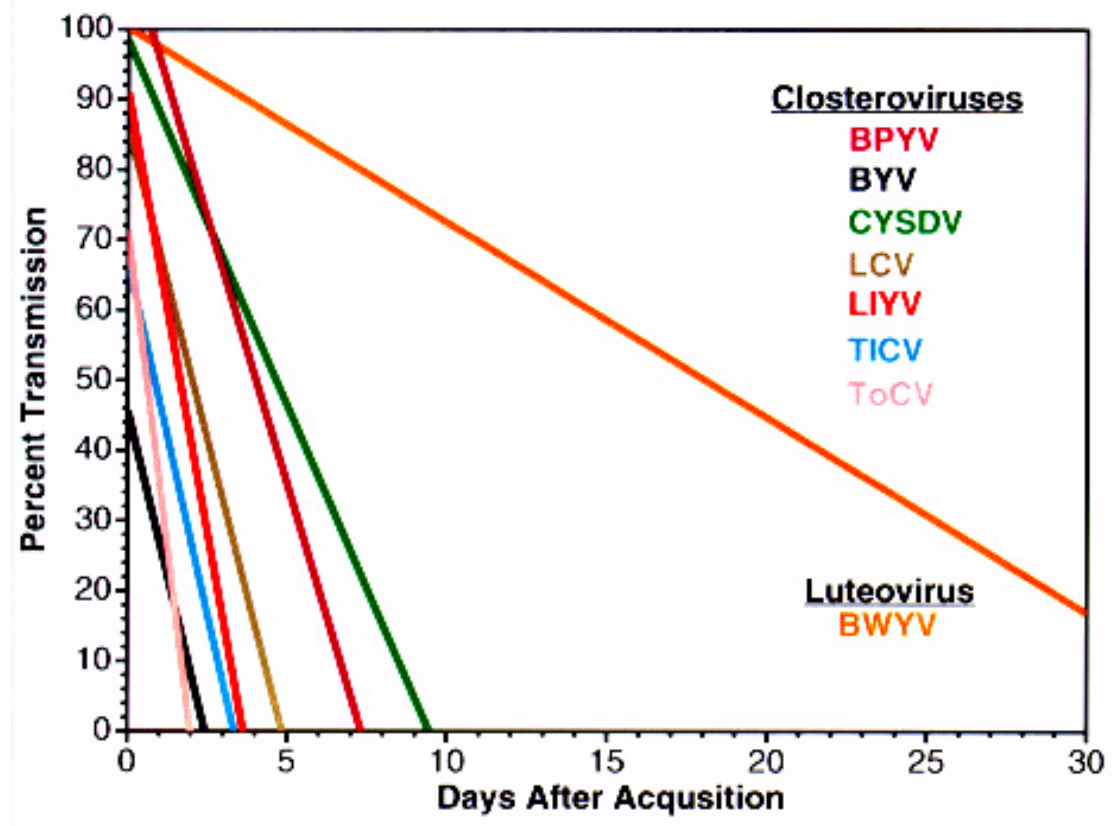

Fig. 5. Virus persistence (retention of the virus in the vector in daily serial transfers) for six whitefly-transmitted closteroviruses compared with an aphid-transmitted closterovirus, beet yellows virus (BYV) (71), and to an aphid-transmitted luteovirus beet western yellows virus (BWYV) (19). The whitefly-transmitted closteroviruses shown are: lettuce infectious yellows virus (LIYV) (30), lettuce chlorosis virus (LCV) (33), cucurbit yellow stunting disorder virus (CYSDV) (11), beet pseudo-yellows virus (BPYV) (20), tomato infectious chlorosis virus (TICV) (32), and tomato chlorosis virus (ToCV) (J. E. Duffus, unpublished results). These persistence values differ substantially from those of BWYV. The time each virus persists in the vector (in days) is plotted against percent transmission for each virus. 
vector. Based on squash silvering records from Israel (4), it appears that B. tabaci biotype $\mathrm{B}$ may have existed in the Middle East at least since the early 1960s. Although the $\mathrm{B}$ biotype has since become well established in the New World, CYSDV has not been reported in the United States. It is likely that as researchers, growers, and industry personnel become better informed regarding symptoms induced by CYSDV and BPYV, and as diagnostic probes become available, their presence will be realized in many geographical areas and crops.

\section{LIYV}

A distinct whitefly-transmitted yellowing virus of lettuce, sugar beet, cucurbits, and other weed and crop hosts, LIYV was found in the desert regions of California and Arizona in $1981(10,28,30)$. LIYV is the most thoroughly characterized bicomponent closterovirus $(45,46)$ and is the type member of the new genus in the Closteroviridae. Molecular characterization of LIYV has been thoroughly reviewed by Klaassen et al. $(45,46)$ and Falk and Klaassen (36). Like BPYV, LIYV has a wide host range and has greatly affected, not only lettuce (Fig. 6), but also 45 species in 15 plant families (30). LIYV can easily be considered a major virus of cucurbits, but it will be discussed with regard to the epi- phytotic in lettuce crops that has occurred in the desert southwestern United States during the 1980s. In contrast to CYSDV, which has been found only in the Middle East and Spain, and whose vector has origins in the Old World $(8,26)$, LIYV and its whitefly vector $B$. tabaci biotype A are primarily restricted to the desert southwestern United States. B. tabaci biotype A was widespread in the southwestern United States and the Sonoran Desert of Mexico prior to 1990, as was LIYV.

In 1981, lettuce, cucurbit, and sugar beet crops in the southwestern United States were ubiquitously infected with LIYV, resulting in losses exceeding \$20 million in one growing season (30). Lettuce yielded 50 to $75 \%$ lower than in previous years, and sugar beets yielded 20 to $30 \%$ less than expected. Ironically, lettuce growers made huge profits during the 1981 growing season due to a sharp increase in market prices.

Bemisia populations changed during the 1980s and early 1990s in the Sunbelt states of the United States, and throughout the tropical and subtropical zones worldwide due to the displacement of biotype A by biotype B $(9,14)$. Whereas LIYV is transmitted efficiently by biotype A and is retained in the vector for 3 days in daily serial transfers, it is transmitted 100-fold less efficiently by biotype B $(25,26)$. Nev- ertheless, virus disease incidence and cropping patterns were greatly affected by the introduction of the $\mathrm{B}$ biotype, because its populations increased to much higher levels than its predecessor's. Popularized descriptions at the time included words like "explosion" to describe the high increases in populations. At that time, the usual cropping pattern in the desert southwestern United States was late-summer melons followed by fall-planted lettuce and sugar beets. Cotton, although not a host for LIYV, served as a favored food and rearing host for the whitefly populations $(6,30)$. When cotton was defoliated, whiteflies moved to melons. Melons provided a major increase host for populations of whiteflies and of LIYV. Entering the crucial late-summer period, LIYV normally was at its lowest level of the year and survived only in weeds. Without melons, therefore, the incidence of the virus would be relatively low late in the season on newly planted lettuce and sugar beet crops (30). Growers were advised to eliminate the fall melons but were reluctant to do so because of the economic value of the crop. Feeding by the biotype B whiteflies can cause severe damage to plants $(14,85)$. Feeding damage by the new biotype was so destructive to melons that the fall melon crop was abandoned due to whitefly feeding in spite of growers' efforts to salvage it
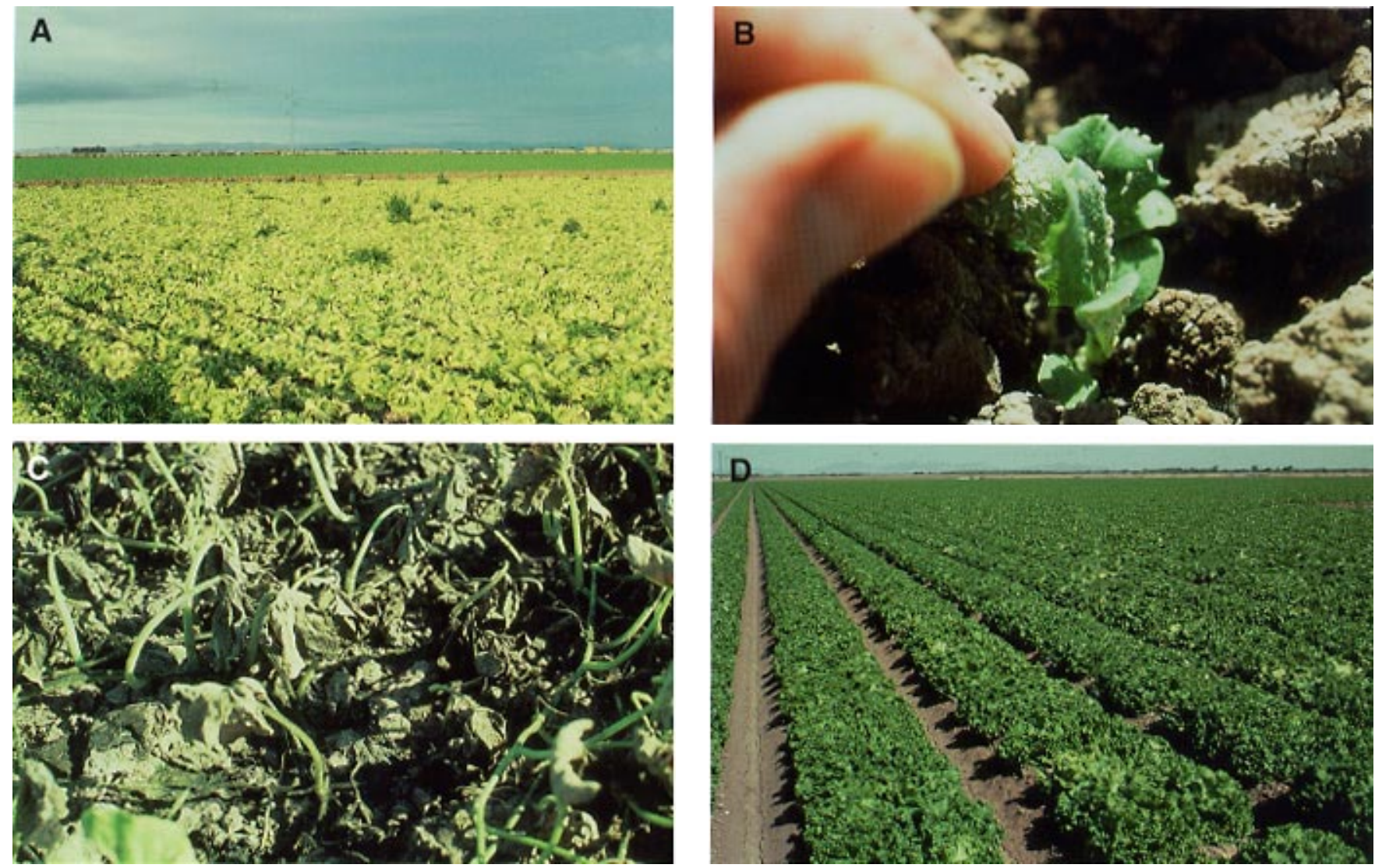

Fig. 6. (A) Lettuce field in 1990-91 100\% infected with lettuce infectious yellows virus showing yellowing and stunting. (B) Whitefly populations on newly emerging lettuce seedlings when fall melon crops were still being planted. (C) Melon planting destroyed by whitefly feeding of the B biotype. (D) Lettuce field after fall melons were not planted in the Imperial Valley of California (1991 to present). 
(Fig. 6). As a result, in 1992 and since, Thus, in spite of record whitefly populations, with the green bridge of fall melons eliminated, LIYV has been present in very (Fig. 7) $(25,31,36)$. Although LIYV is still present in this area, it currently is not considered a problem. If late-summer melons again gain acreage and changes in vector populations occur, a problem with LIYV may reappear in the future.

\section{LCV}

Once LIYV disease incidence became negligible, another virus of lettuce, LCV (33), was recognized (Fig. 8). Symptoms of LCV are similar to those of LIYV in lettuce and sugar beet. LCV is transmitted efficiently by both the A and B biotypes of B. tabaci. An important difference between LIYV and LCV is the fact that LCV does not infect cucurbits (33). LCV is distinct from LIYV based on different mobilities of dsRNAs, lack of cross-hybridization in dot blot hybridizations, and lack of serological cross-reactions (33; G. C. Wisler, unpublished data). LCV has no major summer hosts, so its ability to survive emulates that of LIYV without cucurbits. The currently low levels of LCV and LIYV are likely due to their low incidence in surviving weeds and the heavy use of the insecticide imidacloprid for whitefly control. However, resistance to imidacloprid has already been demonstrated in some areas $(61,62)$, and in crops where whiteflies are not controlled, e.g., sugar beet, LCV has been found recently (77), although it has not yet become a significant problem. almost no fall melons have been planted. low incidence since 1992 (less than 0.1\%)

A dynamic epidemiological situation potentially exists among LCV, LIYV, their two major whitefly vectors, and the crop and weed hosts they infect in the southwestern United States. Both viruses are currently present at low levels. LIYV and LCV may have existed as mixed infections for some time before the latter was recognized as a distinct virus. Changes in cropping patterns, whitefly vector populations, and pesticide use could result in a serious future outbreak of either virus at any time.

\section{TICV}

TICV was the first reported WTC infecting tomato (32) (Fig. 9A) and is the second confirmed bipartite closterovirus (81). TICV is transmitted specifically by the greenhouse whitefly, T. vaporariorum, and persists in the vector for 4 days (23.0-h half-life) in daily serial transfers. At the time TICV was first reported, BPYV was the only closterovirus known to be transmitted by the greenhouse whitefly. However, TICV cannot be confused with BPYV because the latter does not infect tomatoes. Additionally, no cross reactions have been observed between BPYV and TICV using serological and molecular probes $(32,48-50,81)$.

TICV was first found in tomato fields in Orange County, California, in 1993. In one season, the growers in this county suffered $\$ 2$ million in losses (32). The elevated virus incidence coincided with high populations of the greenhouse whitefly, and TICV could be found infecting surrounding weeds, including bristly oxtongue (Picris echioides L.), tree tobacco (Nicotiana glauca Graham), and wild arti-

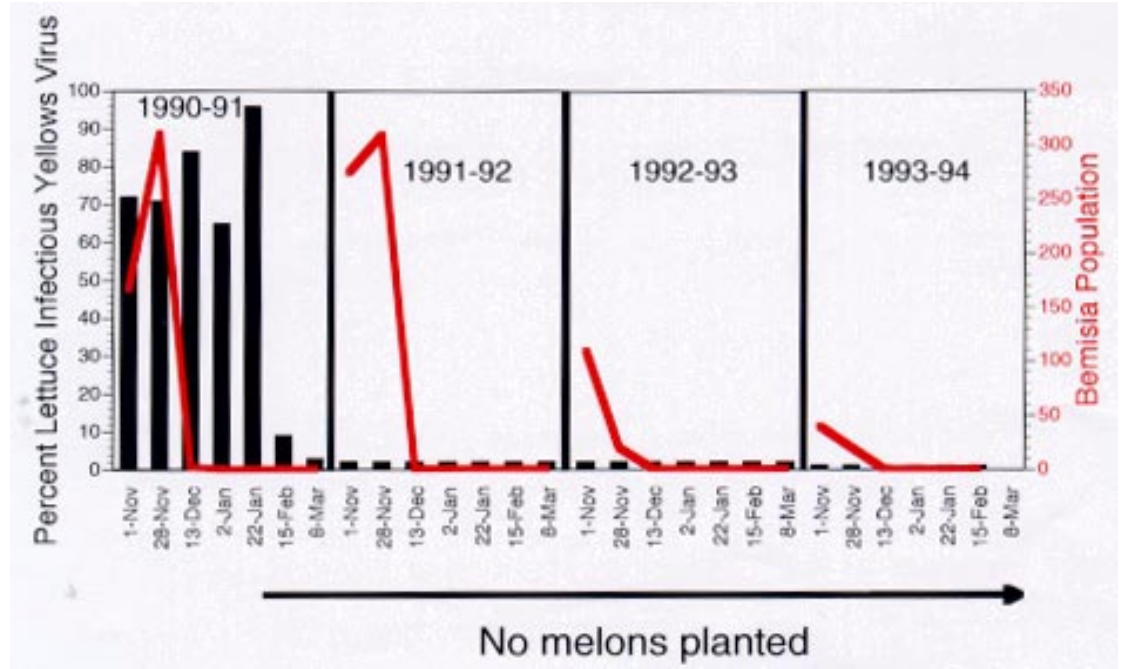

Fig. 7. Lettuce infectious yellows virus infection and Bemisia populations in lettuce in the Imperial Valley, California, from 1990 to 1994. Virus incidence (visual counts) and whitefly populations made in 2-min collections with a hand-held collection device (15) from 20 randomly sampled mature lettuce fields at each date. Because of the destructive effect of the B biotype of Bemisia, virtually no melons were planted in the fall growing seasons from 1991 through 1993 (31). Percent lettuce infectious yellows virus (LIYV) indicated by black bars and Bemisia populations by red lines. Thus, in spite of record whitefly populations during the years since the B biotype became predominant, the absence of the major source of LIYV (fall melons) $(25,26)$ resulted in a very low incidence of LIYV. choke (Cynara cardunculus L.) (32). Since its discovery, TICV has been found primarily in commercial greenhouse-grown tomatoes and tomatoes used in breeding programs. TICV has now been identified in Italy and North Carolina, as well as in several areas in California (27). TICV infects several ornamental species grown as greenhouse bedding plants, including ranunculus, China aster (Fig. 9B), and petunia $(31,81)$. In one greenhouse where tomato and lettuce breeding programs were established, both vegetable and surrounding ornamental crops were infected. These hosts were being grown in the same areas where high populations of the greenhouse whitefly were also present.

Like other bipartite closteroviruses, TICV has a modal length ranging from 850 to $900 \mathrm{~nm}$ (H.-Y. Liu, unpublished data). Ultrastructural observations in our lab also show typical vesiculation in phloem cells of TICV-infected plants. Serological and nucleic acid probes have been developed in our lab and work well for diagnosis of TICV in tomato and other hosts $(48,50)$.

\section{ToCV}

While the distribution and incidence of TICV were being elucidated, two additional bicomponent WTCs were detected in tomato. One of these, ToCV, has been well characterized (78-80). Known in Florida since 1989 as the yellow leaf disorder of tomato (67) (Fig. 9C), efforts to identify a virus using standard diagnostic techniques including serology, electron and light microscopy, and mechanical inoculation of indicator plants were unsuccessful $(67,78)$. In December of 1995, samples were submitted to our laboratory because of the similarity of ToCV symptoms to those of TICV. Transmission studies using whiteflies, dot blot hybridizations using specific nucleic acid probes to TICV RNA 1 and 2, and serological analyses with antisera to TICV showed that this was a new virus of tomatoes distinct from TICV (78-80) (Fig. 10). Subsequent studies have shown that ToCV is the second distinct bipartite WTC infecting tomatoes, with particle lengths ranging from 800 to $850 \mathrm{~nm}$. Degenerate

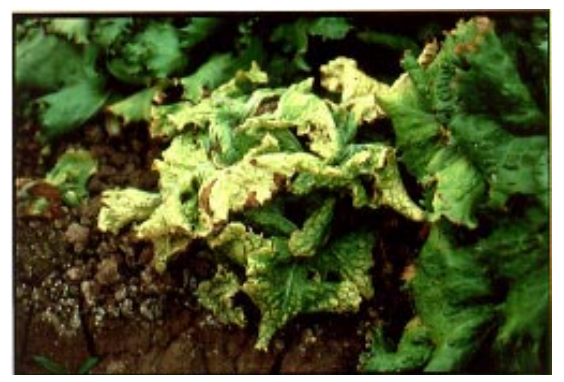

Fig. 8. Field symptoms of lettuce chlorosis virus discovered in Imperial Valley, California, after lettuce infectious yellows virus was virtually eliminated from the area. 
primers, which were designed to amplify the HSP70 coding region of WTCs by RTPCR (72), failed to amplify ToCV despite repeated attempts using a range of experimental conditions. The nucleotide sequence of $\mathrm{ToCV}$ from the regions targeted by degenerate PCR primers revealed three differences in the sequence of ToCV at nondegenerate positions that would limit or prevent its amplification by these primers (79). In addition, transmission studies indicated that ToCV is transmitted not only by T. vaporariorum (as is TICV) but by the greenhouse whitefly, B. tabaci biotypes A and $\mathrm{B}$, and the banded-winged whitefly, $T$. abutilonea (Haldeman), with a retention of 1 to 2 days, the shortest reported for the WTCs (Fig. 5).

Both TICV and ToCV infect a large number of weed, agronomic, and ornamental plant hosts. Although field infections of potato have not been reported, greenhouse studies reveal that it is susceptible to both TICV and ToCV, with symptoms resembling those induced by the potato leafroll luteovirus. Host range studies indicate that, whereas TICV infects lettuce, ToCV does not. TICV symptoms of necrotic interveinal flecking and chlorosis on the indicator plants $N$. benthamiana and $N$. clevelandii are more severe than those induced by ToCV. ToCV symptoms on these hosts include the interveinal chlorosis but do not induce the necrosis (J. E. Duffus, unpublished).

Symptoms of TICV and ToCV are very similar in tomato, typical of other members of this genus. They include interveinal yellowing, necrotic flecking, rolling of lower leaves, and thickened, crispy lower leaves, while the upper leaf canopy appears normal. Yield reductions occur primarily due to the loss of photosynthetic area. Although no obvious fruit symptoms occur, production is reduced by decreased size and number of fruit. It appears that ToCV is widely distributed. In addition to several counties in north central Florida, preliminary surveys using dot blot hybridization analyses with probes to ToCV RNA 1 and 2 show that ToCV also occurs in greenhouse-grown tomatoes from Colorado and Louisiana (79).

During the course of our surveys for the presence of TICV and ToCV, one additional whitefly-transmitted, apparently bipartite (based on dsRNA analysis) virus of tomato was identified in our lab. This unnamed virus does not react with probes specific to TICV and ToCV in dot blot hybridizations, nor with TICV antisera in Western blot analyses (ToCV antisera is not available). This virus is transmitted by the greenhouse whitefly, shows two prominent dsRNAs similar in mobility to TICV and ToCV, and has been detected using RTPCR with degenerate primers (72) that target the HSP70 gene from WTCs.

\section{WTCs Infecting Sweet Potato}

The first report of the sweet potato virus disease (SPVD) was from Nigeria (66). SPVD results from a mixed infection with the sweet potato feathery mottle potyvirus (SPFMV) and a Bemisia-transmitted closterovirus $(13,76)$ and is considered to be a serious disease of sweet potato (Ipomoea batatas (L.) Lam.) worldwide. First and most convincing evidence for a bipartite genome of the sweet potato closterovirus was provided by Hoyer et al. (40), who sequenced the genome of a Kenyan isolate that has a genomic organization very similar to that of LIYV $(44,45)$ but has a coat protein duplicate of $79 \mathrm{kDa}$, which is considerably larger than that of LIYV. Single infection with this bicomponent closterovirus is usually latent in sweet potato and is detected by diagnostic symptoms of mild chlorosis and severe stunting in Ipomoea setosa Ker. Since its first report in 1976, several studies have been made on viruses with characteristics similar to the bicomponent closteroviruses from North and South America, Kenya, the United States, and Israel. Names given to these virus isolates include sweet potato chlorotic stunt virus (SPCSV) (66), sweet potato virus disease-associated closterovirus (SPVD-aC) $(60,75,76)$, and sweet potato sunken vein virus (SPSVV) $(13,40$, 41,74). Current thinking is that SPCSV accurately describes the symptoms induced by this virus as a single infection, and it is the first name associated with this bicomponent closterovirus; thus, it is the favored designation (S. Winter and H. J. Vetten, personal communication).

Sweet potato is grown throughout the world, is vegetatively propagated, and is subject to virus indexing programs as part of international trade and germ plasm repositories. Tests are conducted primarily by graft inoculation of the indicator plant $I$. setosa. Diagnostic tests are not widely available for the bicomponent closterovirus isolates infecting sweet potato. However, antiserum has been developed to the Kenyan isolate of SPSVV $(40,41,74)$, and a test has been recently developed for several isolates of SPVD-aC that involves the RTPCR of a portion of the HSP70. A study using RT-PCR followed by single-strand conformation polymorphism (75; S. Winter, personal communication) revealed a close relationship with over $90 \%$ overall nucleotide identity in multiple sequence alignment of HSP fragments among SPVD-aC isolates from African countries, the United States, Israel, Brazil, Argentina, and Taiwan. Likewise, serological studies using both polyclonal and monoclonal antibodies to the Kenyan and Israeli isolates of SPSVV indicate the geographically diverse isolates are closely related. All
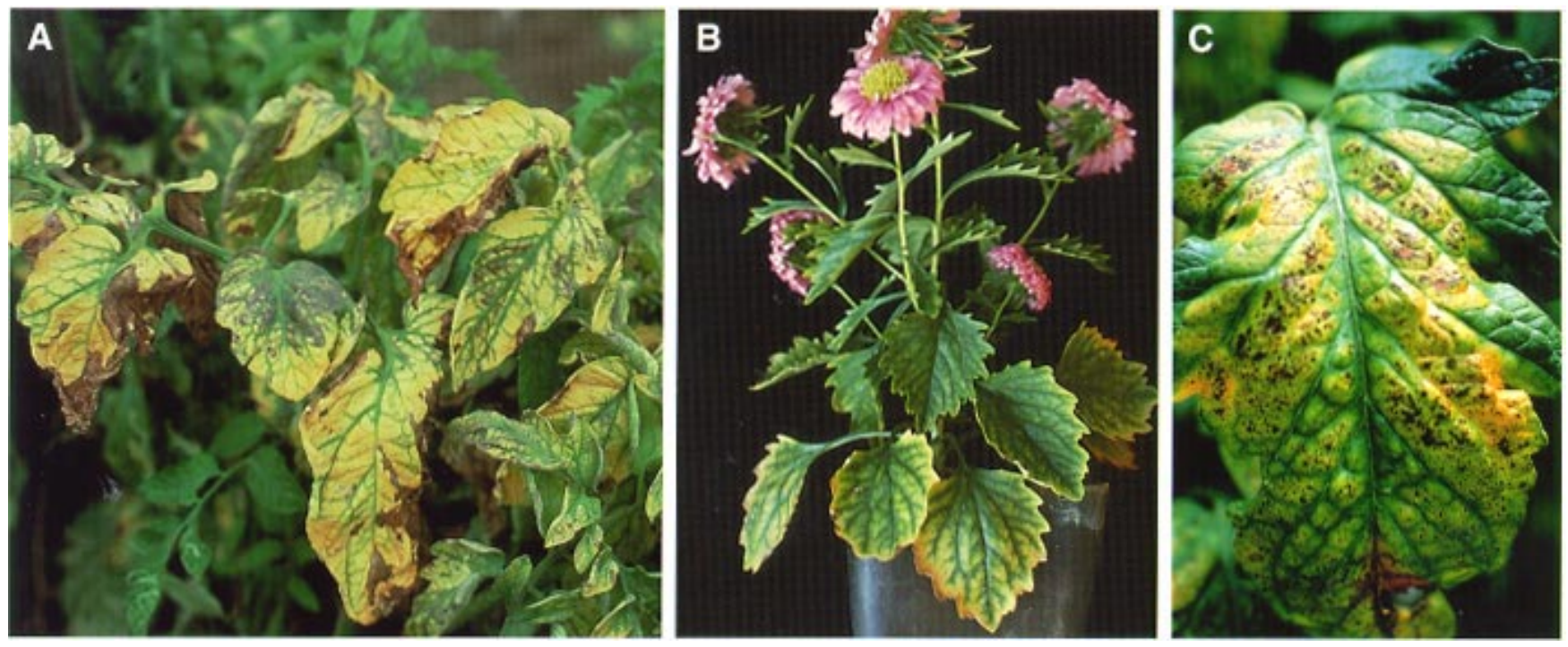

Fig. 9. (A) Leaf symptoms of tomato infectious chlorosis virus (TICV) infecting field-grown tomatoes in Orange County, California. (B) TICV infecting China aster showing typical interveinal yellowing. (C) Tomato chlorosis virus (ToCV) infecting greenhouse-grown tomatoes in north central Florida. (ToCV photo courtesy G. W. Simone). 
closterovirus-like isolates infecting sweet potato have bipartite genomes with indistinguishable mobilities in gel analysis. Although the clustering of geographically diverse isolates is different depending on whether serological or molecular results are compared, all bicomponent closterovirus isolates studied are closely related (S. Winter and H. J. Vetten, personal communication).

In spite of the several names designated for the bicomponent closterovirus isolates infecting sweet potato, there is apparently only one virus, SPCSV, which is distributed throughout the world, with many isolates that are closely related but can be differentiated into two serotypes, an East African and a non-East African serotype (74), according to serological and molecular analyses. Those studied are Bemisiatransmitted and have bipartite genomes. Relationships have been established, and diagnostic tests have been developed that identify isolates from diverse geographic origins. Studies continue to further identify the diversity within this group. Other than the fact that all isolates are reported to be transmitted by $B$. tabaci, specific retention properties of these isolates are not known.

\section{Summary and Outlook}

Biological and molecular tools are now available to diagnose whitefly-transmitted viruses. Recent work by Karasev et al. (44) and Tian et al. (72) provides degenerate primers that amplify a portion of the HSP70 of several aphid- and whiteflytransmitted closteroviruses. A corrobora-

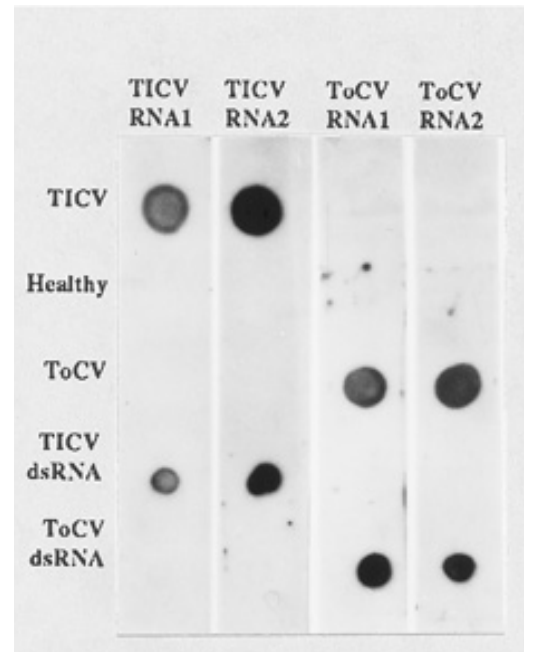

Fig. 10. Reciprocal dot blot hybridization analysis using digoxigenin-11-UTP-labeled RNA transcripts that represent portions of RNA 1 and RNA 2 from tomato infectious chlorosis virus (TICV) and tomato chlorosis virus (ToCV). Samples are, from top to bottom, total nucleic acid extracts from TICV-infected tomato, healthy tomato, ToCV-infected tomato, TICV dsRNA, and ToCV dsRNA. No cross-reactivity has been observed between these two bicomponent closteroviruses of tomato. tive assay, however, is often needed for diagnosis and verification. As seen with ToCV, differences can occur whereby even so-called universal probes may fail to detect a previously undescribed virus. The identity with a known virus or of a new, previously unidentified one can be made using biological properties such as host range, vector transmission and specificity, and persistence (Fig. 5) (Table 1). These biological properties are also critical in assessing the potential effects the viruses have on economically important crops. The dynamic situation seen with LIYV and LCV is a good example of the effect specific vector population and local virusvector reservoirs have on epiphytotics.

At least two additional whitefly-transmitted clostero- or clostero-like viruses have been reported: abutilon yellows virus (22) and diodia vein chlorosis virus (47) (Table 1). These viruses have not been thoroughly characterized, except that their particle morphologies, cytological characteristics, and whitefly transmission indicate they are closteroviruses. A report of nandina stem pitting virus (NSPV) (2) is suggestive of a WTC. NSPV has flexuous, rod-shaped particles of 696 to $830 \mathrm{~nm}$ and was neither mechanically nor aphid-transmitted. This virus was reported before most of the WTCs were recognized, and thus this type of transmission was not tested. Recently, we transmitted a bipartite WTC from Nandina domestica Thunb. cv. Fire Power, and a portion of the HSP70 coding region was amplified. It is not known at this time if this is the same NSPV as was previously reported in 1983.

The very recent detection (since 1991) of at least eight new and distinct bicomponent WTCs indicates the possibility that more such viruses of this category exist. These viruses have probably been in existence for years. Indeed, the unrecognized symptomatology, the extremely low titer characteristic of these viruses, and their limitation to phloem tissues can make detection by serological or nucleic acidbased assays difficult.

Even universal probes can result in a failure to detect a new virus that is different from others previously described. With the aid of whitefly transmission trials, often the virus can be transmitted to susceptible assay hosts (typically Physalis wrightii, Nicotiana clevelandii, or $N$. benthamiana) in the absence of a positive laboratory assay. Once probes are developed, they can be used to aid in the detection of these viruses, their distribution, host range, and movement. All of these factors are important in establishing integrated pest management strategies that include virus-free propagative materials, crop isolation by species and maturity, and insecticide deployment to minimize the development of tolerance to pesticides. It is possible that, if other crops such as the tomato we recently studied are investigated using whitefly transmission, many new viruses of this closterovirus genus will also be found.

\section{Acknowledgments}

We thank A. A. Cortez, R. Ruiz, and J. Knight for their excellent technical assistance with whitefly rearing and transmissions. We thank G. W. Simone for providing ToCV-infected tomato samples, G. W. Simone and F. W. Zettler for critical review of this manuscript, and $\mathrm{S}$. Winter and H. J. Vetten for helpful discussions on sweet potato closteroviruses.

\section{Literature Cited}

1. Agranovsky, A. A., Boyko, V. P., Karasev, A V., Koonin, E. V., and Dolja, V. V. 1991. Putative $65 \mathrm{kDa}$ protein of beet yellows closterovirus is a homologue of HSP70 heat shock proteins. J. Mol. Biol. 217:603-610.

2. Ahmed, N. A., Christie, S. R., and Zettler, F. W. 1983. Identification and partial characterization of a closterovirus infecting Nandina domestica. Phytopathology 73:470-475.

3. Bar-Joseph, M., Garnsey, S. M., and Gonsalves, D. 1979. The Closteroviruses: A distinct group of elongated plant viruses. Adv. Virus Res. 25:93-167.

4. Be'eri, Y., and Kapuler, B. 1963. Summer squash. Pages 235-240 in: Growing Vegetables. Part B. Sifriyyat Hassadeh, Tel Aviv.

5. Bellows, T. S., Perring, T. M., Gill, R. J., and Headrick, D. H. 1994. Description of a species of Bemisia [Homoptera, Aleyrodidae]. Ann. Entomol. Soc. Am. 87:195-206.

6. Blua, M. J., Perring, T. M., Nuessly, G. S., Duffus, J. E., and Toscano, N. C. 1994. Impact of cropping patterns on Bemisia tabaci and LIYV. Environ. Entomol. 23:1422-1427.

7. Boyko, V. P., Karasev, A. V., Agranovsky, A A., Koonin, E. V., and Dolja, V. V. 1992. Coat protein gene duplication in a filamentous RNA virus of plants. Proc. Natl. Acad. Sci. USA 89:9156-9160.

8. Brown, J. K. 1994. Current status of Bemisia tabaci as a plant pest and virus vector in agroecosystems worldwide. FAO Plant Prot. Bull. 42:3-33.

9. Brown, J. K., Frohlich, D. R., and Rosell, R. C. 1995. The sweet potato or silverleaf whiteflies: Biotypes of Bemisia tabaci or a species complex? Annu. Rev. Entomol. 40:511-534.

10. Brown, J. K., and Nelson, M. R. 1986. Whitefly-borne viruses of melons and lettuce in Arizona. Phytopathology 76:236-239.

11. Celix, A., Lopez-Sese, A., Almarza, N., Gomez-Guillamon, M. L., and RodriguezCerezo, E. 1996. Characterization of cucurbit yellow stunting disorder virus, a Bemisia tabaci-transmitted closterovirus. Phytopathology 86:1370-1376.

12. Coffin, R. S., and Coutts, R. H. A. 1995 Relationships among Trialeurodes vaporariorum-transmitted yellowing viruses from Europe and North America. J. Phytopathol. 143:375-380.

13. Cohen, J., Frank, A., Vetten, H. J., Lesemann, D. E., and Loebenstein, G. 1992. Purification and properties of closterovirus-like particles associated with a whitefly transmitted disease of sweet potato. Ann. Appl. Biol. 121:257268.

14. Cohen, S., Duffus, J. E., and Liu, H.-Y. 1992. A new Bemisia tabaci (Gennadius) biotype in southwestern United States and its role in silverleaf of squash and transmission of lettuce infectious yellows virus. Phytopathology 82:86-90.

15. Cohen, S., Duffus, J. E., Perry, R., and Dawson, R. 1989. A collection and marking sys- 


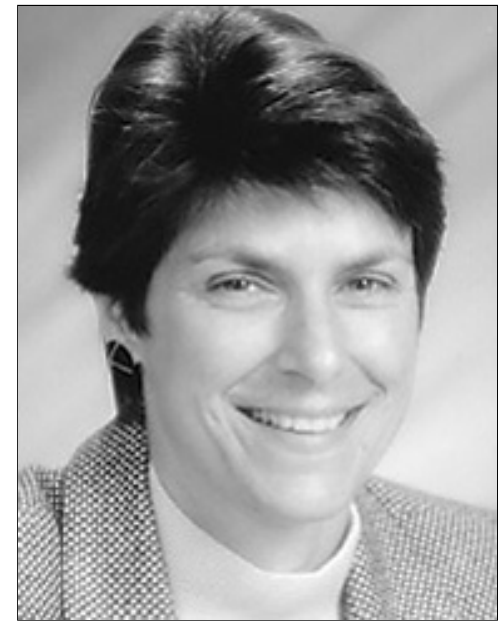

Gail C. Wisler

Dr. Wisler is a research plant pathologist at the USDA-ARS Crop Improvement and Protection Unit in Salinas, California. She received her B.S. in biology from the College of William and Mary. Her M.S. and Ph.D. were from the University of Florida in plant pathology. Her current research interests include soilborne viruses and whitefly-transmitted viruses of sugar beet and vegetables, their molecular characterization, and the development of management strategies.

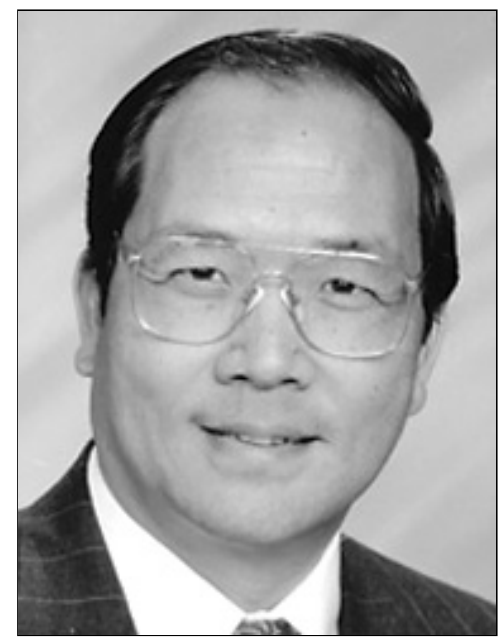

Hsing-Yeh Liu

Dr. Liu is a plant pathologist at the USDA-ARS Crop Improvement and Protection Unit in Salinas, California. He received his Ph.D. in plant pathology in 1981 from the University of California, Riverside. $\mathrm{He}$ has conducted research on virus diseases of sugar beet and vegetables, with special emphasis on biological, serologi$\mathrm{cal}$, and molecular characterization of viruses, virus-vector relationships, epidemiology, and control strategies of vector-borne virus diseases.

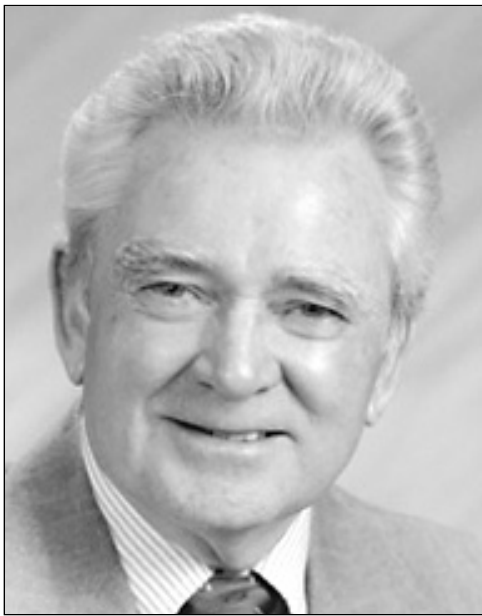

James E. Duffus

Dr. Duffus is a research plant pathologist with the USDA-ARS Crop Improvement and Protection Unit in Salinas, California. He received his B.S. in botany in 1951 from Michigan State College and his Ph.D. in plant pathology in 1955 from the University of Wisconsin. He joined the USDAARS in 1955. His area of research includes sugar beet and vegetable virus diseases, with a special emphasis on insect-transmitted viruses and their ecology and control.

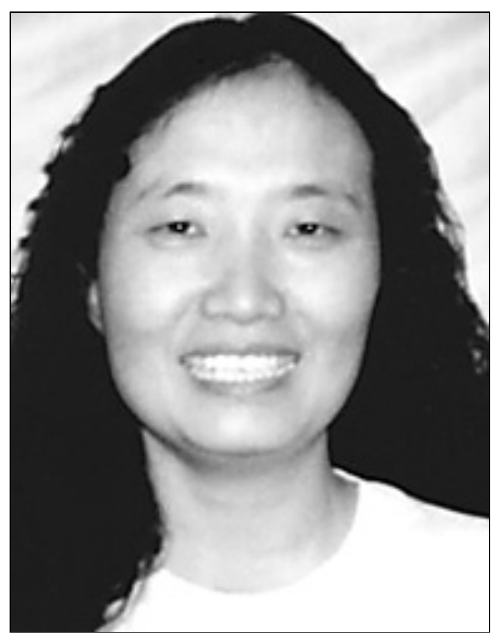

\section{Ruhui Li}

Dr. $\mathrm{Li}$ is a research associate at the Department of Plant Pathology, Auburn University, Auburn, Alabama. She received her B.S. in plant protection from Yunnan Agricultural University, P. R. China, and her Ph.D. in plant pathology from the University of Florida in 1995. She has worked on detection and molecular characterization of whitefly-transmitted closteroviruses of vegetables. tem suitable for epidemiological studies on whitefly-borne viruses. Plant Dis. 73:765768.

16. Costa, H. S., and Brown, J. K. 1991. Variation in biological characteristics and esterase patterns among populations of Bemisia tabaci and the association of one population with silverleaf symptom induction. Entomol. Exp. Appl. 61:211-219.

17. Coutts, R. H. A., and Coffin, R. S. 1996. Beet pseudo-yellows virus is an authentic closterovirus. Virus Genes 13:179-181.

18. Dolja, V. V., Karasev, A. V., and Koonin, E. V. 1994. Molecular biology and evolution of closteroviruses: Sophisticated build-up of large RNA genomes. Annu. Rev. Phytopathol. 32:261-285.

19. Duffus, J. E. 1960. Radish yellows, a disease of radish, sugar beets, and other crops. Phytopathology 50:389-394.

20. Duffus, J. E. 1965. Beet pseudo-yellows virus, transmitted by the greenhouse whitefly, Trialeurodes vaporariorum. Phytopathology 55:450-453.

21. Duffus, J. E. 1977. Aphids, viruses, and the yellow plague. Pages 361-383 in: Aphids as Virus Vectors. Academic Press, Inc., New York

22. Duffus, J. E. 1987. Whitefly transmission of plant viruses. Pages 73-91 in: K. F. Harris, ed. Current Topics in Vector Research. Vol. 1. Springer-Verlag, New York.

23. Duffus, J. E. 1992. Whitefly vectors: Increasing threat to world agriculture. Proc. XIX Intl. Congr. Entomol. p. 352.

24. Duffus, J. E. 1994. Diseases vectored by whiteflies; etiology, ecology, geographical distribution and possible control measures. Arab. J. Plant Prot. 12:143-148.

25. Duffus, J. E. 1995. Whitefly transmitted yellowing viruses of the Cucurbitaceae. Pages 12-16 in: Cucurbitaceae '94. G. E. Lester and J. R. Dunlap, eds. Gateway Printing, Westlaco, TX.

26. Duffus, J. E. 1996. Whitefly-borne viruses Pages 255-263 in: Bemisia 1995 Taxonomy, Biology, Damage, Control and Management Intercept, Ltd., Andover, UK.

27. Duffus, J. E., Caciagli, P., Liu, H.-Y., Wisler, G. C., and Li, R. H. 1996. Occurrence of tomato infectious chlorosis virus in Europe. Page 33 in: Silverleaf Whitefly: 1996 Supplement to the Five Year Plan. U.S. Dep. Agric. Agric. Res. Serv. No. 1996-01.

28. Duffus, J. E., and Flock, R. A. 1982. Whitefly-transmitted disease complex in the desert southwest. Calif. Agric. 36:4-6.

29. Duffus, J. E., and Johnstone, G. R. 1981. Beet pseudo-yellows virus in Tasmania. Austral. Plant Pathol. 10:68-69.

30. Duffus, J. E., Larsen, R. C., and Liu, H. Y. 1986. Lettuce infectious yellows virus-A new type of whitefly-transmitted virus. Phytopathology 76:97-100

31. Duffus, J. E., and Liu, H.-Y. 1994. The effects of whitefly population changes on lettuce in fectious yellows virus epidemiology. Page 48 in: Sweet Potato Whitefly: 1994 Supplement to the Five Year Plan. U.S. Dep. Agric. Agric. Res. Serv. No. 125.

32. Duffus, J. E., Liu, H.-Y., and Wisler, G. C. 1994. Tomato infectious chlorosis virus-A new clostero-like virus transmitted by Trialeurodes vaporariorum. Eur. J. Plant Pathol. 102:219-226.

33. Duffus, J. E., Liu, H.-Y., Wisler, G. C., and Li, R. H. 1996. Lettuce chlorosis virus-A new whitefly-transmitted closterovirus. Eur. J Plant Pathol. 102:591-596.

34. Esau, K. 1968. Viruses in Host Plants: Form Distribution and Pathological Effects; University of Wisconsin, Madison.

35. Esau, K., and Hoefert, L. L. 1971. Cytology 
of beet yellows virus infection in Tetragonia. I. Parenchyma cells in infected leaf. Protoplasma 72:255.

36. Falk, B. W., and Klaassen, V. A. 1995. Bemisia 1995: Taxonomy, Biology, Damage, Control and Management. Intercept, Ltd., Andover, UK. pp. 265-275.

37. Francki, R. I. B., Fauquet, C. M., Knudson, D., and Brown, F. 1991. Classification and nomenclature of viruses. Fifth Report of the International Committee on Taxonomy of Viruses. Arch. Virol. Suppl. 2. pp. 345-347.

38. Hassan, A. A., and Duffus, J. E. 1991. A review of a yellowing and stunting disorder of cucurbits in the United Arab Emirates. Emir. J. Agric. Sci. 2:1-16.

39. Hoefert, L. L., Esau, K., and Duffus, J. E. 1970. Electron microscopy of Beta leaves infected with beet yellow stunt virus. Virology 42:814-824.

40. Hoyer, U., Jelkmann, W., Maiss, E., and Vetten, H. J. 1996. Sweet potato sunken vein virus: Another bipartite closterovirus transmitted by Bemisia tabaci Genn. Xth Int. Congr. Virol. Jerusalem. p. 89

41. Hoyer, U., Maiss, E., Jelkmann, W., Lesemann, D.-E., and Vetten, H. J. 1996. Identification of the coat protein gene of a sweet potato sunken vein closterovirus isolate from Kenya and evidence for a serological relationship among geographically diverse closterovirus isolates from sweet potato. Phytopathology 86:744-750.

42. Hristova, D. P., and Natskova, V. T. 1986. Interrelation between Trialeurodes vaporariorum West and the virus causing infectious chlorosis in cucumbers. Biologie-Virologie. Comptes Rend. Acad. Bulgare Sci. 39(8):105118.

43. Jorda-Gutierrez, D., Gomez-Guillamon, M. L., Juarez, M., and Alfaro-Gracia, A. 1993. Clostero-like particles associated with a yellows disease of melons in southeastern Spain. Plant Pathol. 42:722-727.

44. Karasev, A. V., Nikolaeva, O. V., Koonin, E. V., Gumpf, D. J., and Garnsey, S. M. 1994. Screening of the closterovirus genome by degenerate primer-mediated polymerase chain reaction. J. Gen. Virol. 75:1415-1422.

45. Klaassen, V. A., Boeshore, M., Dolja, V. V., and Falk, B. W. 1995. Partial characterization of the lettuce infectious yellows virus genomic RNAs, identification of the coat protein gene and comparison of its amino acid sequence with those of other filamentous RNA plant viruses. J. Gen. Virol. 75:15251533.

46. Klaassen, V. A., Boeshore, M. L., Koonin, E. V., Tian, T., and Falk, B. W. 1996. Genome structure and phylogenetic analysis of lettuce infectious yellows virus, a whitefly-transmitted, bipartite closterovirus. Virology 208:99-110.

47. Larsen, R. C., Kim, K. S., and Scott, H. A. 1991. Properties and cytopathology of Diodia vein chlorosis virus-A new whitefly-transmitted virus. Phytopathology 81:227-232.

48. Li, R. H., Wisler, G. C., Liu, H.-Y., and Duffus, J. E. 1996. Comparison of diagnostic techniques for detecting tomato infectious chlorosis virus. (Abstr.) Phytopathology 86:S12-S13.

49. Li, R. H., Wisler, G. C., Liu, H.-Y., and Duffus, J. E. 1997. Partial nucleotide sequence analysis of tomato infectious chlorosis virus (TICV). (Abstr.) Phytopathology 87:S58.

50. Li, R. H., Wisler, G. C., Liu, H.-Y., and Duffus, J. E. 1998. Comparison of diagnostic techniques for detecting tomato infectious chlorosis virus. Plant Dis. 82:84-88.

51. Lister, R. M., and Bar-Joseph, M. N. 1981. Handbook of Plant Virus Infections and Comparative Diagnosis. E. Kurstak, ed. Elsevier, Amsterdam, North Holland. pp. 809-844.
52. Liu, H.-Y., Cohen, S., and Duffus, J. E. 1992. The use of isozyme patterns to distinguish sweetpotato whitefly (Bemisia tabaci) biotypes. Phytoparasitica 20:187-194.

53. Liu, H.-Y., and Duffus, J. E. 1990. Beet pseudo-yellows virus: Purification and serology. Phytopathology 80:866-869.

54. Lot, H., Delecolle, B., and Lecoq, H. 1982. A whitefly-transmitted virus causing muskmelon yellows in France. Acta Hortic. 127:175-182.

55. Lot, H., Onillon, J. C., and Lecoq, H. 1980. Une nouvelle maladie a virus de la laitue deserre: La jaunisse transmise par la mouche blanche. Rev. Hortic. 209:31-34

56. Markham, P. G., Bedford, I. D., Liu, S., Frolich, D., Rosell, R., and Brown, J. K. 1995. The transmission of geminiviruses by biotypes of Bemisia tabaci (Gennadius). Pages 69-75 in: Bemisia 1995: Taxonomy, Biology, Damage, Control and Management. Intercept, Ltd., Andover, UK

57. Murphy, F. A., Fauquet, C. M., Bishop, D. H. L., Ghabrial, S. A., Jarvis, A. W., Martelli, G. P., Mayo, M. A., and Summers, M. D. 1995. Pages 461-464 in: Virus Taxonomy: Classification and Nomenclature of Viruses. Springer-Verlag, New York.

58. Pappu, H. R., Karasev, A. V., Anderson, E. J., Pappu, S. S., Hilf, M. E., Febres, V. J., Eckloff, R. M. G., McCaffery, M., Boyko, V., Gowda, S., Dolja, V. V., Koonin, E. V., Gumpf, D. J., Cline, K. C., Garnsey, S. M., Dawson, W. O., Lee, R. F., and Niblett, C. L. 1994. Nucleotide sequence and organization of eight 3 '-open reading frames of the citrus tristeza closterovirus genome. Virology 199:35-46.

59. Perring, T. M., Cooper, A. D., Rodriquez, R.
J., Farrar, C. A., and Bellows, T. S. 1993. Identification of a whitefly species by genomic and behavioral studies. Science 259:74-79.

60. Pio-Ribeiro, G., Winter, S., Jarrett, T. L., Demski, J. W., and Hamilton, R. I. 1996. Detection of sweet potato virus disease-associated closterovirus in a sweet potato accession in the United States. Plant Dis. 80:551-554.

61. Prabhaker, N., Toscano, N., Castle, S., and Henneberry, T. 1995. Hydroponic bioassay technique to monitor responses of whiteflies to imidacloprid. Page 89 in: Silverleaf Whitefly: 1995 Supplement to the Five Year National Research and Action Plan. U.S. Dep. Agric. Agric. Res. Serv.

62. Prabhaker, N., Toscano, N., Castle, S., and Henneberry, T. 1996. Evaluation of insecticide rotations and mixtures as a resistance management strategy for whiteflies. Page 95 in: Silverleaf Whitefly: 1996 Supplement to the Five Year National Research and Action Plan. U.S. Dep. Agric. Agric. Res. Serv.

63. Pringle, C. R. 1996. Virus Taxonomy 1996 A Bulletin from the Xth International Congress of Virology in Jerusalem. Arch. Virol. 141:2251-2256.

64. Ragozzino, A. D., Alioto, D., Lengo, C., and Lahoz, E. 1988. The yellowing virus and mycoplasma diseases of lettuce in Campania and Latium regions. Pages 145 in: Proc. Congr. Mediterr. Phytopathol. Union. 7th, Granada.

65. Rosemeyer, M. E., Brown, J. K., and Nelson, M. R. 1986. Five viruses isolated from fieldgrown buffalo gourd (Cucurbita foetidissima), a potential crop for semiarid lands. Plant Dis. 70:405-409.

66. Schaefers, G. A., and Terry, E. R. 1976. Insect transmission of sweet potato disease agents in

\section{An advertisement appears in the printed journal in this space.}


Nigeria. Phytopathology 66:642-645.

67. Simone, G. W., Hochmuth, R. C., Wisler, G. C., Duffus, J. E., Liu, H.-Y., and Li, R. H. 1996. A new whitefly-vectored closterovirus of tomato in Florida. Pages 71-74 in: Tom. Inst. Proc.

68. Snyder, R. G. 1995. Greenhouse tomatoesThe basics of successful production. Pages 36 in: Proc. Greenhouse Tom. Seminar, Montreal, Canada.

69. Soria, C., Gomez-Guillamon, M. L., and Duffus, J. E. 1991. Transmission of the agent causing a melon yellowing disease by the greenhouse whitefly Trialeurodes vaporariorum in southeast Spain. Neth. J. Plant Pathol. 97:289-296.

70. Stevens, J. 1995. Controlling geminiviruses. American Vegetable Grower. p. 24F-24G.

71. Sylvester, E. S. 1956. Beet yellows virus transmission by the green peach aphid. J. Econ. Entomol. 49:789-800.

72. Tian, T., Soong, J., Wisler, G. C., Duffus, J. E., and Falk, B. W. 1996. Generation and cloning of specific cDNAs corresponding to four whitefly-transmitted viruses using RTPCR and degenerate oligonucleotide primers corresponding to the closterovirus gene encoding the heat shock protein 70 homolog. Phytopathology 86:1167-1173.

73. Van Dorst, H. J. M., Huijberts, N., and Bos, L. 1980. A whitefly transmitted disease of glasshouse vegetables, a novelty for Europe. Neth. J. Plant Pathol. 85:311-313.
74. Vetten, H. J., Hoyer, U., Maiss, E., Lesemann, D. E., and Jelkmann, W. 1996. Serological detection and discrimination of geographically diverse isolates of sweet potato sunken vein closterovirus. (Abstr.) Phytopathology 86:S100.

75. Winter, S., Korbler, M., and Kollner, U. Detection and differentiation of sweet potato closteroviruses by RT-PCR and singlestranded conformation polymorphism. Eur. Phytopathol. Soc. In press.

76. Winter, S., Purac, A., Leggett, F., Frison, E. A., Rossel, H. W., and Hamilton, R. I. 1992. Partial characterization and molecular cloning of a closterovirus from sweet potato infected with the sweet potato virus disease complex from Nigeria. Phytopathology 82:869-875.

77. Wisler, G. C., Duffus, J. E., and Gerik, J. S. 1997. First report of lettuce chlorosis virus naturally infecting sugarbeets in California. Plant Dis. 81:550.

78. Wisler, G. C., Duffus, J. E., Liu, H.-Y., Li, R. H., Simone, G. W., and Hochmuth, R. C. 1996. A new, whitefly-transmitted virus infecting tomato from Florida. (Abstr.) Phytopathology 86:S71-S72.

79. Wisler, G. C., Li, R. H., Liu, H.-Y., and Duffus, J. E. 1997. Partial molecular and cytological analyses of tomato chlorosis virus. (Abstr.) Phytopathology 87:S104

80. Wisler, G. C., Li, R. H., Liu, H.-Y., Lowry, D. S., and Duffus, J. E. Tomato chlorosis virus: A new whitefly-transmitted, phloem-limited bipartite closterovirus of tomato. Phytopathology. In press.

81. Wisler, G. C., Liu, H.-Y., Klaassen, V. A. Duffus, J. E., and Falk, B. W. 1996. Tomato infectious chlorosis virus has a bipartite genome and induces phloem-limited inclusions characteristic of the closteroviruses. Phytopathology 86:622-626.

82. Woudt, L. P., deRover, A. P., deHaan, P. T. and vanGrinsven, M. Q. J. M. 1993. Sequence analysis of the RNA genome of cucumber chlorotic spot virus (CCSV), a whiteflytransmitted closterovirus. (Abstr.) Intl. Congr. Virol. IX. Glasgow, Scotland. p. 326.

83. Yamashita, S., Doi, Y., Yora, K., and Yoshino, M. 1979. Cucumber yellows virus: Its transmission by the greenhouse whitefly, Trialeurodes vaporariorum (Westwood), and the yellowing disease of cucumber and muskmelon caused by the virus. Ann. Phytopathol. Soc. Jpn. 45:484-496.

84. Yarwood, C. E., and Sylvester, E. S. 1959. The half-life concept of longevity of plant pathogens. Plant Dis. Rep. 43:125-128.

85. Yokomi, R. K., Hoelmer, K. A., and Osborne, L. S. 1990. Relationships between the sweetpotato whitefly and the squash silverleaf disorder. Phytopathology 80:895-900.

86. Zenbayashi, R., Shimazaki, Y., and Shibukawa, S. 1988. Some properties of cucumber yellows virus occurred on cucurbitaceous crops in Japan. Abstr. Int. Congr. Plant Pathol. 5th, Kyoto, Japan 50:1-24.

\section{ERRATUM / Volume 82, Number 3, 1998}

In the feature article "Ecology and Epidemiology of Whitefly-Transmitted Closteroviruses" by G. C. Wisler, J. E. Duffus, H.-Y. Liu, and R. H. Li, on pages 270280 , the first full paragraph on page 272 should read:

In contrast to the geminiviruses, which show easily recognizable symptoms on infected plants, whitefly-transmitted closteroviruses (WTCs) typically cause symptoms that are easily attributed to other causes, such as physiological or nutritional disorders, or even pesticide phytotoxicity. In spite of these atypical virus symptoms, diseases caused by LIYV, the type member of the newly proposed genus Crinivirus of the family Closteroviridae, caused losses due to infections of lettuce, sugar beets, and melons reaching $\$ 20$ million in a single growing season in 1981 (30). In addition to causing difficult-to-recognize virus symptoms, the WTCs usually exist in low titers in infected plants and are generally restricted to the phloem tissue, thus making diagnosis and isolation even more difficult. It also is likely that the WTCs exist as mixed infections (65) with the more conspicuous geminiviruses and thus have gone unnoticed. 